\title{
界面活性剤水溶液の抵抗低減乱流境界層に及ぼす溶液温度の影響*
}

\author{
玉 野 真 司*1, 伊 藤 基 之*1 \\ 井上武文*2, 横田和 彦*1
}

\section{Effects of Temperature of Surfactant Solutions on Drag-Reducing Turbulent Boundary Layer}

\author{
Shinji TAMANO*3, Motoyuki ITOH, \\ Takefumi INOUE and Kazuhiko YOKOTA \\ ${ }^{* 3}$ Graduate School of Engineering, Nagoya Institute of Technology, \\ Gokiso-cho, Showa-ku, Nagoya-shi, Aichi, 466-8555 Japan
}

\begin{abstract}
In this study, the influence of a drag-reducing surfactant on the turbulent boundary layer was extensively investigated under different solution temperatures using a two-component laser-Doppler velocimetry system. The surfactant solution used here was a mixture of cetyltrimethyl ammonium chloride (CTAC) with sodium salicylate as counterion, which was dissolved in tap water. The temperature of surfactant solution was $T=20,25,30$, and $35^{\circ} \mathrm{C}$. It is found that the drag reduction ratio $D R$ for $C=65$ and $100 \mathrm{ppm}$ becomes smaller with the increase of the temperature from $T=25$ to $35^{\circ} \mathrm{C}$, and the $D R$ at $T=20^{\circ} \mathrm{C}$ is smaller than $D R$ at $T=25^{\circ} \mathrm{C}$. We introduced three distinct regimes of drag reduction, which were referred to as low drag reduction (LDR), high drag reduction (HDR), and maximum drag reduction (MDR) regimes. The distributions of the mean velocity, the wallnormal turbulence intensity, and the Reynolds shear stress could be clarified by these three regimes, while the streamwise turbulence intensity profile could not be explained.
\end{abstract}

Key Words : Non-Newtonian Fluid, Turbulent Flow, Boundary Layer, LDV, Velocity Distribution, Surfactant Solution, Drag Reduction

\section{1. 緒言}

著者ら ${ }^{(1)}$ は, 界面活性剂添加による抵抗低減メカニ ズムの解明のためには, 内部流れにおける知見に加え て外部流れにおける知見も必要であるという考えのも と, 外部流れである界面活性剤水溶液の抵抗低減境界 層流れの速度場計測を行ってきた。これにより, 高分 子水溶液の抵抗低減乱流境界層流れ(2) (3) ならびに界 面活性剂水溶液の円管内乱流 ${ }^{(4)}{ }^{(5)}$ およびチャネル乱 流 $^{(6) \sim(10)}$ においては見られない境界層中央部付近に おける主流方向乱れ強さ分布の付加的な極大值の存在 を明らかにした ${ }^{(1)}$.また，ごく最近著者ら ${ }^{(11)}$ は，溶 液濃度 $65 \mathrm{ppm}, 100 \mathrm{ppm}$ および $150 \mathrm{ppm}$, 溶液温度 $20^{\circ} \mathrm{C}$ において界面活性剤水溶液の濃度の影響を調べ ることにより，この付加的な極大值の存在と抵抗低減 率との関係について報告している。しかしながら, 界 面活性剤水溶液の温度の影響は調べられておらず, 利 用可能な実測データは円管内乱流およびチャネル乱流

* 原稿受付 2007 年 10 月 24 日.

*1 正員, 名古屋工業大学大学院工学研究科(W 466-8555 名古 屋市昭和区御器所町).

*2 川崎重工業 (株) 明石工場 (画673-8666 明石市川崎町 1-1).

E-mail : tamano.shinji@nitech.ac.jp
のものと比べると不十分である. 特に, 界面活性剂水 溶液の抵抗低減流れの速度場は溶液温度の影響を強く 受けることから, 溶液濃度 $65 \mathrm{ppm}, 100 \mathrm{ppm}$ および $150 \mathrm{ppm}$, 溶液温度 $20^{\circ} \mathrm{C}$ において観察されている主 流方向乱れ強さ分布の付加的な極大值が他の溶液温度 においても同様に見られるかどうかについては不明で ある。

最近, 実験的研究に加えて, 粘弾性流体の抵抗低減 乱流境界層の直接数值シミュレーション (DNS) が行な われるようになってきた ${ }^{(12) \sim(14)}$. しかしながら,こ れらの数值的研究では, 主に希薄高分子水溶液におけ る抵抗低減乱流境界層を対象としており, 界面活性剤 水溶液に特有のレオロジ一特性は考慮されていない. そのため, 界面活性剂水溶液の抵抗低減乱流境界層の 抵抗低減メカニズムに関する知見, 特に, 境界層中央 部付近において見られる主流方向乱れ強さ分布の付加 的な極大值に関する知見についてはこれまでに得られ ていない.

本研究では, 2 次元レーザドップラー流速計 (LDV) を用いて, 既報 ${ }^{(11)}$ の溶液濃度 $65 \mathrm{ppm}$ および $100 \mathrm{ppm}$, 溶液温度 $20^{\circ} \mathrm{C}$ に加えて, 溶液温度 $25^{\circ} \mathrm{C}, 30^{\circ} \mathrm{C}$ およ゙ $35^{\circ} \mathrm{C}$ におけるゼロ圧力勾配平板上乱流境界層の平均速 
(a)

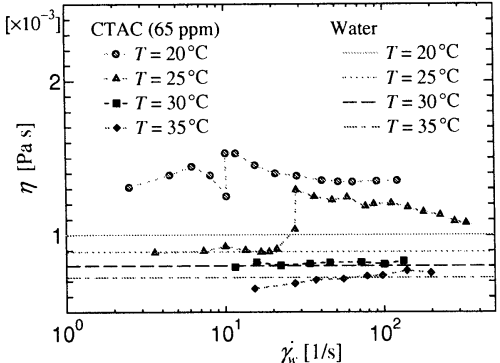

(b)

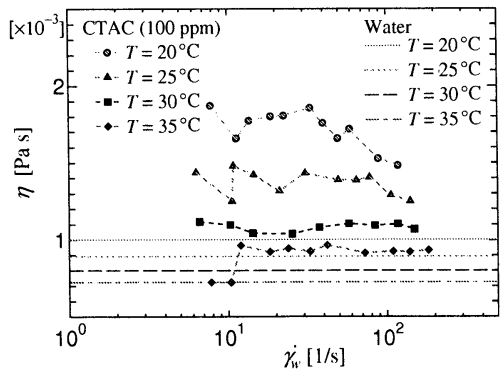

Fig. 1 Effect of solution temperature on shear viscosity: (a) $65 \mathrm{ppm}$, (b) $100 \mathrm{ppm}$.

度および乱れ統計量の分布を計測し, 界面活性剤水溶液 の抵抗低減乱流境界層に及ぼす溶液温度の影響を明ら かにした. 特に, 粘弹性流体の抵抗低減流れを抵抗低減 率の大きさにより，低抵抗低減 (Low Drag Reduction: LDR), 高抵抗低減 (High Drag Reduction: HDR), 最 大抵抗低減 (Maximum Drag Reduction: MDR) の 3 つに分類することで ${ }^{(15)}$ ，平均速度分布および乱れ統 計量の分布を整理した.

\section{2. 実験装置および方法}

実験には， $300 \times 300 \times 1500 \mathrm{~mm}$ のアクリル製の 開水路測定部を持つ回流水槽を用いた。測定部には $20 \times 295 \times 1700 \mathrm{~mm}$ のアクリル製のテストプレートを 底面に対して垂直に設置した．テストプレート前緣か ら $100 \mathrm{~mm}$ の位置に直径 $2 \mathrm{~mm}$ のトリップワイヤを 取り付けることにより，テストプレート上に乱流境界 層を発達させた。

界面活性剂水溶液として，水道水を溶媒とし，これ に陽イオン界面活性㓮であるへキサデシルトリメチ ルアンモニウムクロライド $\left(\mathrm{C}_{16} \mathrm{TACl}, \mathrm{CTAC}\right)$ と対 イオンであるサリチル酸ナトリウム $(\mathrm{NaSal}) を$ 同モ ル量溶解したものを使用した。本研究では, 界面活性 剤 (CTAC) の重量濃度を $65 \mathrm{ppm}$ および $100 \mathrm{ppm}$ と した.

流速の測定には 2 次元 LDV(Model 1543-A-A03, 日 本カノマックス㑣製) を使用した。 主流速度 $U_{e} \simeq 300$ $\mathrm{mm} / \mathrm{s}$ のもと, チャネル底面からの高さ $150 \mathrm{~mm}$, 前
Table 1 Effect of solution temperature on boundary layer parameters and friction velocity for surfactant solutions of $C=65$ and $100 \mathrm{ppm}$.

\begin{tabular}{cccccc}
\hline \hline & $T\left({ }^{\circ} \mathrm{C}\right)$ & $\delta(\mathrm{mm})$ & $\delta^{*}(\mathrm{~mm})$ & $\theta(\mathrm{mm})$ & $u_{\tau}(\mathrm{mm} / \mathrm{s})$ \\
\hline \multirow{3}{*}{ CTAC } & 20 & 23.0 & 4.87 & 2.65 & 8.50 \\
$65 \mathrm{ppm}$ & 25 & 22.2 & 5.13 & 2.58 & 7.70 \\
& 30 & 28.1 & 4.69 & 3.25 & 11.3 \\
& 35 & 29.8 & 4.79 & 3.43 & 13.0 \\
\hline \multirow{3}{*}{ CTAC } & 20 & 22.2 & 5.45 & 2.90 & 9.60 \\
$100 \mathrm{ppm}$ & 25 & 20.1 & 4.89 & 2.52 & 8.50 \\
& 30 & 24.3 & 4.74 & 2.75 & 10.5 \\
& 35 & 29.3 & 4.60 & 3.21 & 12.5 \\
\hline \hline
\end{tabular}

縁からの主流方向距離 $x=1000 \mathrm{~mm}$ の位置において LDV 計測を行なった. LDV 計測時の作動流体の温度 $T$ は, $20^{\circ} \mathrm{C}, 25^{\circ} \mathrm{C}, 30^{\circ} \mathrm{C}$, および $35^{\circ} \mathrm{C}$ と変化させ た。また, 2 台の循環式冷却器により, 測定中の溶液 温度を $\pm 0.1^{\circ} \mathrm{C}$ 以内に保った。

なお，実験装置ならびに LDV 計測の詳細について

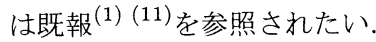

\section{3. 実験結果および考察}

$3 \cdot 1$ せん断粘度 溶液濃度 $65 \mathrm{ppm}$ および $100 \mathrm{ppm}$ の界面活性剂水溶液について, 溶液温度 $T=$ $20,25,30,35^{\circ} \mathrm{C}$ におけるせん断速度 $\dot{\gamma}_{w} 1 / \mathrm{s}$ とせん断 粘度 $\eta \mathrm{Pa} \cdot \mathrm{s}$ の関係をそれぞれ図 1(a)および1(b)に 示す．せん断粘度の測定には内径 $d=5.07 \mathrm{~mm}$ の細管 粘度計を使用し，細管全体をウォータージャケット構 造にすることにより，溶液温度 $T$ を設定温度の \pm 0.5 ${ }^{\circ} \mathrm{C}$ 以内に保ち測定を行った．溶液濃度 $65 \mathrm{ppm}$ の場 合， $T=20^{\circ} \mathrm{C}$ および $25^{\circ} \mathrm{C}$ ではそれぞれ，せん断速度 が $101 / \mathrm{s}$ および $201 / \mathrm{s}$ 付近において，せん断粘度は 急激に上昇し $(\mathrm{SIS})^{(16)}$, その後, せ九断速度の増加に 伴いせん断粘度は単調に減少する (Shear-thinning) の

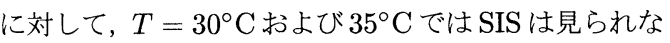
い. また, 同じ温度の水の值と比較して, せん断粘度 の值は $T=20^{\circ} \mathrm{C}$ および $25^{\circ} \mathrm{C}$ では大きく, $T=30^{\circ} \mathrm{C}$ および $35^{\circ} \mathrm{C}$ ではほぼ同じである。

一方, 溶液濃度 $100 \mathrm{ppm}$ の場合, 溶液温度 $T=$ $20^{\circ} \mathrm{C}, 25^{\circ} \mathrm{C}$ および $35^{\circ} \mathrm{C}$ では, せん断速度 $\dot{\gamma}_{w}=101 / \mathrm{s}$ 付近において SIS となるが, $T=30^{\circ} \mathrm{C}$ ではSIS は見ら れずほぼ一定值となる。 また, 溶液温度 $T=20^{\circ} \mathrm{C}$ お よび $25^{\circ} \mathrm{C}$ ではデータのばらつきはあるものの Shearthinning が見られるが， $T=30^{\circ} \mathrm{C}$ および $35^{\circ} \mathrm{C}$ では 見られない，なお，溶液濃度 $100 \mathrm{ppm}$ の場合, 溶液 温度に依らず，界面活性剂水溶液のせん断粘度は同じ 温度の水のものよりも大きくなる.

3.2 境界層パラメータ 溶液濃度 $C=65$ ppm および $100 \mathrm{ppm}$ について, 溶液温度 $T=$ 
(a)

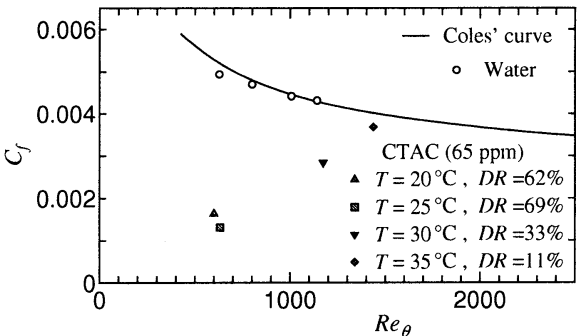

(b)

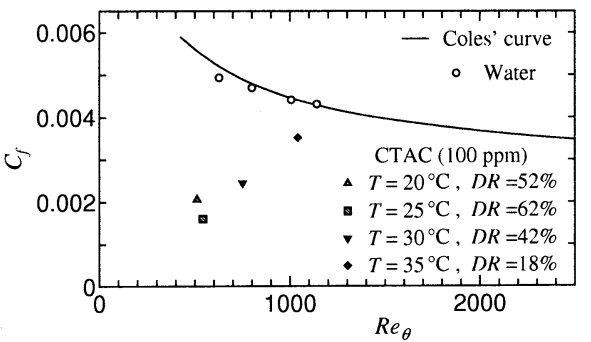

Fig. 2 Effect of solution temperature on streamwise evolution of friction coefficient: (a) 65 ppm, (b) 100 ppm.

$20,25,30,35^{\circ} \mathrm{C}$ における境界層厚さ $\delta$, 排除厚さ $\delta^{*}$, 運動量厚さ $\theta$, および摩擦速度 $u_{\tau}$ の值を表 1 に示す. 界面活性剂水溶液の $u_{\tau}$ の值は, 粘性底層内での平均 速度の測定值を最小 2 乗法により直線近似して得られ る平均速度勾配の值ならびに界面活性剂水溶液のせん 断粘度 (図 1 参照) の值を用いることにより求めた。溶 液濃度 $C=65 \mathrm{ppm}$ および $100 \mathrm{ppm}$ 共に，境界層厚 さ $\delta$, 運動量厚さ $\theta$, および摩擦速度 $u_{\tau}$ は, 溶液温度 が $20^{\circ} \mathrm{C}$ から $25^{\circ} \mathrm{C}$ に高くなると一旦小さくなり，その 後, 溶液温度が $25^{\circ} \mathrm{C}$ から $35^{\circ} \mathrm{C}$ まで高くなるのに伴 い大きくなる.これらの温度依存性は抵抗低減率 $D R$ のものと対応している (表 2 参照). 排除厚さ $\delta^{*}$ につ いては, その発達度合いと抵抗低減率の主流方向変化 (表 2 参照) との間には明確な関連性は見られない.

溶液濃度 $C=65 \mathrm{ppm}$ および $100 \mathrm{ppm}$ について, 壁面摩擦係数 $C_{f}=2\left(u_{\tau} / U_{e}\right)^{2}$ の運動量厚さレイノル ズ数 $R_{\theta}=U_{e} \theta / \nu$ 依存性を図 $2(\mathrm{a})$ および $2(\mathrm{~b})$ に示 す.ここで, $\nu$ は動粘度であり，界面活性剂水溶液の 場合，壁面せん断速度により決定される. 水の場合の $C_{f}$ の測定データ ${ }^{(11)}\left(T=25^{\circ} \mathrm{C}, x=300,500,800\right.$, $1000 \mathrm{~mm})$ はC Coles の曲線 ${ }^{(17)}$ と良く一致している. 界 面活性剂水溶液の場合, 溶液濃度に依らず, $C_{f}$ の值は $T=25^{\circ} \mathrm{C}$ で最小となり, 溶液温度が $25^{\circ} \mathrm{C}$ から $35^{\circ} \mathrm{C}$ まで高くなるのに伴い急激に大きくなり, 水の值に近 づく.

溶液濃度 $C=100 \mathrm{ppm}$ および $150 \mathrm{ppm}$ について, 形状係数 $H=\delta^{*} / \theta$ の $R e_{\theta}$ 依存性を図 $3(\mathrm{a})$ および (a)

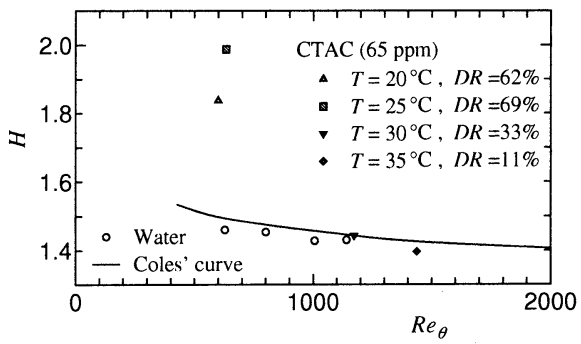

(b)

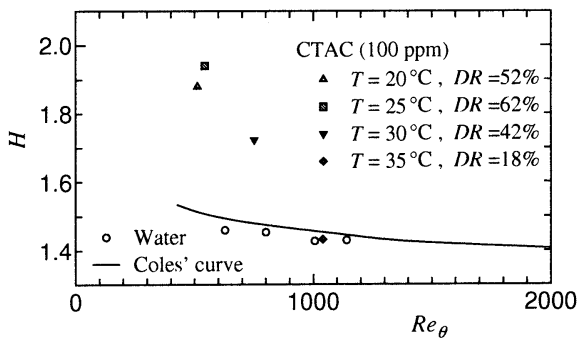

Fig. 3 Effect of solution temperature on streamwise evolution of shape factor: (a) $65 \mathrm{ppm}$, (b) $100 \mathrm{ppm}$.

Table 2 Effect of solution temperature on drag reduction ratio $D R(\%)$.

\begin{tabular}{ccccc}
\hline \hline$C(\mathrm{ppm})$ & $T=20^{\circ} \mathrm{C}$ & $T=25^{\circ} \mathrm{C}$ & $T=30^{\circ} \mathrm{C}$ & $T=35^{\circ} \mathrm{C}$ \\
\hline 65 & 62 & 69 & 33 & 11 \\
100 & 52 & 62 & 42 & 18 \\
\hline \hline
\end{tabular}

3(b) に示す. 水の場合の $H$ の測定データはColes の 曲線 ${ }^{(17)}$ と良く一致している，界面活性剤水溶液の $H$ の值は, $T=20^{\circ} \mathrm{C}$ から $25^{\circ} \mathrm{C}$ に高くなると一旦大き くなり，その後， $T=25^{\circ} \mathrm{C}$ から $35^{\circ} \mathrm{C}$ ま゙高くなる のに伴い急激に小さくなり，水の值と同程度になる. また，界面活性剤水溶液における $H$ の急激な減少は， $C_{f}$ の急激な増加と対応している.

$3 \cdot 3$ 抵抗低減率 溶液濃度 $C=65 \mathrm{ppm}$ および $100 \mathrm{ppm}$ における抵抗低減率 $D R$ の溶 液温度依存性を表 2 に示す. $D R=\left(C_{f_{\text {water }}}-\right.$

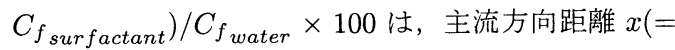
$1000 \mathrm{~mm})$ ならびに主流速度 $U_{e}(\simeq 300 \mathrm{~mm} / \mathrm{s})$ が等 しい界面活性剂水溶液と水の壁面摩擦係数を用いて定 義される.ここで, 水の壁面摩擦係数については, 水 温 $T=25^{\circ} \mathrm{C}$ の測定データ ${ }^{(11)}$ を用いた. 溶液濃度 $C$ に依らず，抵抗低減率 $D R$ は溶液温度 $T$ が $20^{\circ} \mathrm{C}$ か ら $25^{\circ} \mathrm{C}$ に高くなると一旦大きくなり，その後，溶液 温度が $25^{\circ} \mathrm{C}$ から $35^{\circ} \mathrm{C}$ まで高くなるのに伴い小さく なる。

粘弾性流体の抵抗低減流れは抵抗低減率の大きさに より，低抵抗低減 (Low Drag Reduction: LDR), 高抵 
(a)
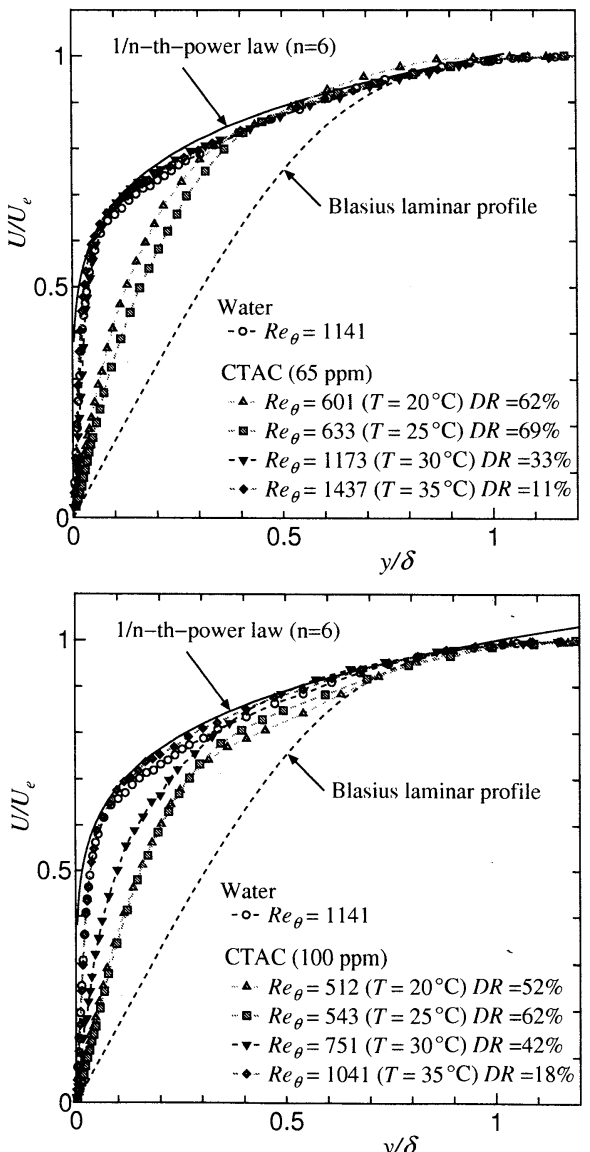

(b)

Fig. 4 Effect of solution temperature on mean velocity: (a) $65 \mathrm{ppm}$, (b) $100 \mathrm{ppm}$.

抗低減 (High Drag Reduction: HDR), 最大抵抗低減 (Maximum Drag Reduction: MDR)の3つに大別さ れる ${ }^{(15)}$. 本研究では, 抵抗低減率が $0<D R<40 \%$ の場合を LDR 領域, $40 \leq D R<60 \%$ の場合を $\mathrm{HDR}$ 領域, $D R \geq 60 \%$ の場合を MDR 領域と定義する. 以 下に示す平均速度分布および乱れ統計量の分布の考察 には, LDR 領域, HDR 領域, およびMDR 領域の分 類を使用する.

3.4 平均速度分布 溶液濃度 $C=65 \mathrm{ppm}$ およ び $100 \mathrm{ppm}$ について, 溶液温度 $T=20,25,30,35^{\circ} \mathrm{C}$ での主流速度 $U_{e}$ により正規化された平均速度 $U / U_{e}$ の 分布をそれぞれ図 $4(\mathrm{a})$ および $4(\mathrm{~b})$ に示す. 図の横軸に は壁面からの無次元距離 $y / \delta$ が用いられている. 図中 の実線および破線はそれぞれ $1 / \mathrm{n}$ 乗則 $(n=6)$ およびブ ラジウスの層流分布 ${ }^{(18)}$ を表す. 溶液濃度 $C=65 \mathrm{ppm}$ では, $T=20^{\circ} \mathrm{C}(D R=62 \%)$ の平均速度 $U / U_{e}$ は, 水の速度分布とブラジウスの層流速度分布のほぼ中間

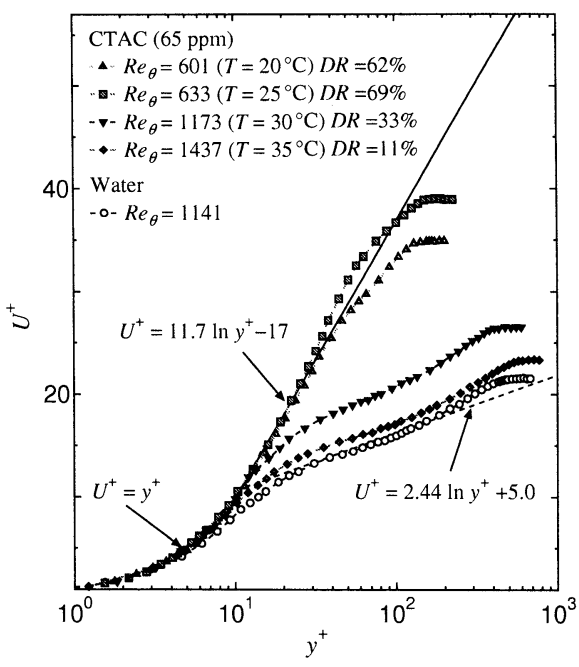

(a)

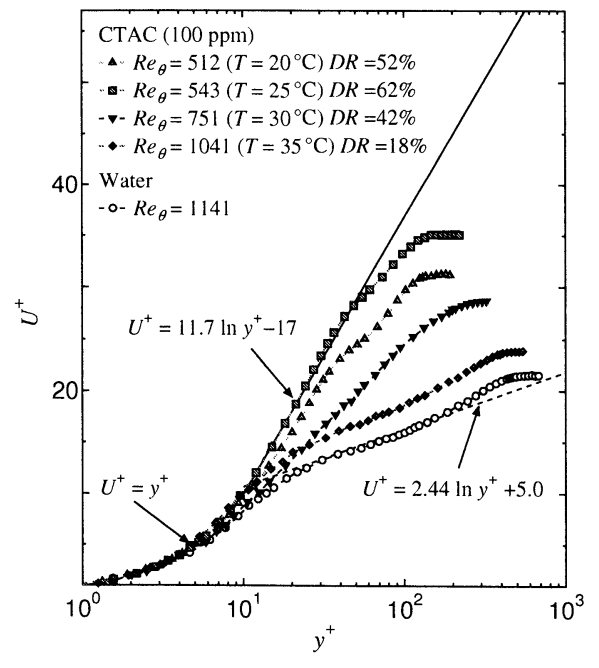

Fig. 5 Effect of solution temperature on mean velocity in wall coordinates: (a) $65 \mathrm{ppm}$, (b) $100 \mathrm{ppm}$.

に位置し, $T=25^{\circ} \mathrm{C}(D R=69 \%)$ の平均速度 $U / U_{e}$ は，さらに層流速度分布に近づく．また， $T=30^{\circ} \mathrm{C}$ $(D R=33 \%)$ および $T=35^{\circ} \mathrm{C}(D R=11 \%)$ の平均速 度 $U / U_{e}$ は水の分布とほぼ一致する. 一方, $C=100$ $\mathrm{ppm}$ では, $T=20^{\circ} \mathrm{C}(D R=52 \%)$ および $T=25^{\circ} \mathrm{C}$ $(D R=62 \%)$ の分布は互いに良く一致し，水の速度分 布とブラジウスの層流速度分布のほぼ中間に位置する. また, $T=30^{\circ} \mathrm{C}(D R=42 \%)$ の分布は, $T=20^{\circ} \mathrm{C}$ お よび $T=25^{\circ} \mathrm{C}$ よりも水の分布に近くなり, $T=35^{\circ} \mathrm{C}$ $(D R=18 \%)$ の分布は, 水の分布にほぼ一致する.

以上の結果より, 外層スケールの平均速度分布は, LDR 領域 $(0<D R<40 \%)$ では水の分布にほぼ一致 すること, $\mathrm{HDR}$ 領域 $(40 \leq D R<60 \%)$ では抵抗低 
減率の増加と共にブラジウスの層流速度分布に近づく こと，および MDR 領域 $(D R \geq 60 \%)$ では水の速度 分布とブラジウスの層流速度分布のほぼ中間に位置す ることが明らかになった。

溶液濃度 $C=65 \mathrm{ppm}$ および $100 \mathrm{ppm}$ について, 摩 擦速度 $u_{\tau}$ により正規化された平均速度 $U^{+}=U / u_{\tau}$ の 分布をそれぞれ図 5(a)および5(b)に示寸. 図の横軸に は壁面からの無次元距離 $y^{+}=u_{\tau} y / \nu$ が用いられてい る. また図には比較のため, $U^{+}=y^{+}$の分布, ニュー トン流体の対数速度分布 $\left(U^{+}=2.44 \ln y^{+}+5.0\right)$, お よび Virk の極限速度分布 ${ }^{(19)}\left(U^{+}=11.7 \ln y^{+}-17\right)$ が示されている.溶液濃度 $C=65 \mathrm{ppm}$ および 100 $\mathrm{ppm}$ 共に, $U^{+}$の值は $y^{+}>10$ において, 抵抗低減 率の増加に伴い大きくなる.このことは，壁変数で正 規化された平均速度 $U^{+}$の分布は抵抗低減率で良く整 理できることを意味しており，従来の実験結果 ${ }^{(1)(11)}$

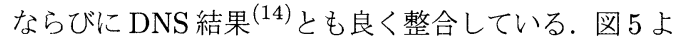
り, LDR 領域 $(0<D R<40 \%)$ では, 平均速度の 対数則領域の傾きは乱流の水のものとほぼ等しく, 平 均速度分布は $D R$ が大きい程より上方にシフトする こと, $\mathrm{HDR}$ 領域 $(40 \leq D R<60 \%)$ では, 平均速度 の対数則領域の傾きが $D R$ が大きい程大きくなるが, Virk の極限速度分のものよりは大きくならないことが 分かる. また，抵抗低減率 $D R=62 \%$ の場合 $(C=65$ $\mathrm{ppm}, T=20^{\circ} \mathrm{C}$ および $C=100 \mathrm{ppm}, T=25^{\circ} \mathrm{C}$ ) には, 平均速度分布の対数則領域の傾きはVirk の極 限速度分布のものとほぼ等しく, 抵抗低減率が最も大 きい $D R=69 \%$ の場合 $\left(C=65 \mathrm{ppm}, T=25^{\circ} \mathrm{C}\right)$ に は，対数則領域の傾きが Virk の極限速度分布のもの よりも大きくなる。つまり, MDR 領域 $(D R \geq 60 \%)$ では, 内層スケールの平均速度の対数則領域の傾きは Virk の極限速度分布のものと同程度またはそれ以上 となる.

以上の結果より, 平均速度 $U^{+}$の分布は, LDR 領 域，HDR 領域，および MDR 領域により良く整理さ れることが明らかになった.

\section{5 主流方向乱れ強さ分布 図 6(a) および6(b)} にそれぞれ，溶液濃度 $C=65 \mathrm{ppm}$ および $100 \mathrm{ppm}$ における $u_{\tau}$ により正規化された主流方向乱れ強さ $u_{r m s}^{++}$の分布を示寸. 溶液濃度 $C=65 \mathrm{ppm}$ の場 合, $T=20^{\circ} \mathrm{C}(D R=62 \%)$ および $T=25^{\circ} \mathrm{C}$ $(D R=69 \%)$ では, $u_{r m s}^{\prime+}$ の壁面近くの最大值は水の ものよりかなり小さくなり, 最大位置 $y / \delta$ は水のもの より大きくなる. $T=30^{\circ} \mathrm{C}(D R=33 \%)$ では, $u_{r m s}^{+}$ の值は水のものより大きい. $T=35^{\circ} \mathrm{C}(D R=11 \%)$ では， $u_{r m s}^{\prime+}$ の最大值は水のものより僅かに大きいが,

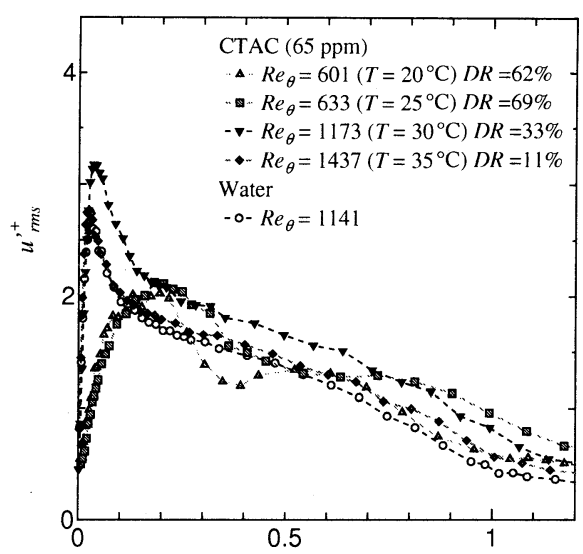

(a)

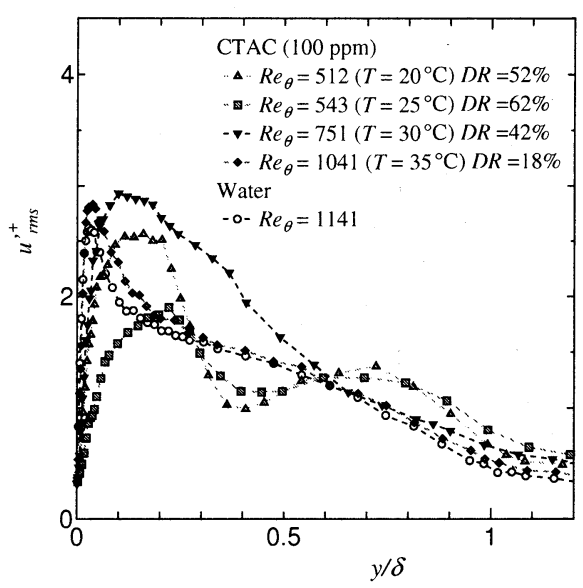

(b)

Fig. 6 Effect of solution temperature on streamwise turbulence intensity: (a) $65 \mathrm{ppm}$, (b) 100 ppm.

その分布は水のものとほぼ一致する。一方, 溶液濃度 $C=100 \mathrm{ppm}$ の場合, $T=25^{\circ} \mathrm{C}(D R=62 \%)$ で は, $u_{r m s}^{\prime+}$ の壁面近くの最大值は水のものよりかなり 小さくなり, 最大位置 $y / \delta$ は水のものより大きくなる. $T=20^{\circ} \mathrm{C}(D R=52 \%)$ では， $u_{r m s}^{\prime+}$ の壁面近くの最 大值は水のものと同程度である. また, その最大位置 $y / \delta$ は水のものより大きいが, $T=25^{\circ} \mathrm{C}$ の場合と比 べるとその差は小さい. $T=30^{\circ} \mathrm{C}(D R=42 \%)$ で は, $u_{r m s}^{+}$の最大值は水のものより大きく, 最大位置 $y / \delta$ は水のものより大きい. $T=35^{\circ} \mathrm{C}(D R=18 \%)$ では， $u_{r m s}^{+}$の最大值は水のものより僅かに大きいが, その分布は水のものとほぼ一致する.

以上の結果から, 主流方向乱れ強さ分布, 特に壁面 近くの最大值の大きさは抵抗低減率 $D R$ の大きさだ けでは整理できないことが明らかになった。 この理由 として, レイノルズ数 $\operatorname{Re}_{\theta}$ の大きさが異なること，な 
らびに乱流境界層の発達度合いが異なることが考えら れる.

界面活性剂水溶液の抵抗低減乱流境界層では，境界 層中央部付近に主流方向乱れ強さの付加的な極大值が 現れることが著者らの以前の研究により明らかにされ ている(1) (11) $u_{r m s}^{\prime+}$ の付加的な極大值が現れる原因は, 境界層外縁近くでは, せん断速度がゼロである境界層外 のポテンシャル流れと境界層内の乱流とが混合されるた め, 紐状ミセルの巨大構造が局所的に存在しなくなり, それに伴い粘弾性効果が小さくなるまたは消失し, 主 流方向乱れ強さが増大することに起因していると考え られている(1) (11). 本研究において, 抵抗低減率が比較 的小さい場合 $\left[C=65 \mathrm{ppm}, T=30^{\circ} \mathrm{C}(D R=33 \%)\right.$, $C=65 \mathrm{ppm}, T=35^{\circ} \mathrm{C}(D R=11 \%), C=100$ $\mathrm{ppm}, T=30^{\circ} \mathrm{C}(D R=42 \%)$, および $C=100 \mathrm{ppm}$, $\left.T=35^{\circ} \mathrm{C}(D R=18 \%)\right]$ には, 境界層中央部におけ る付加的な極大值は見られない。この原因としては, 界面活性剤水溶液の主流方向乱れ強さが $y / \delta<0.5$ に おいて水のものと同程度または水よりも大きくなるた めと考えられる. 一方, 抵抗低減率が比較的大きい場 合 $\left[C=65 \mathrm{ppm}, T=20^{\circ} \mathrm{C}(D R=62 \%), C=100\right.$ $\mathrm{ppm}, T=20^{\circ} \mathrm{C}(D R=52 \%)$, および $C=100 \mathrm{ppm}$, $\left.T=25^{\circ} \mathrm{C}(D R=62 \%)\right]$ には, 境界層中央部におけ る付加的な極大值が現れる.この原因としては, 界面 活性剤水溶液の主流方向乱れ強さが, $0.3<y / \delta<0.5$ においては水のものよりも小さく $y / \delta>0.5$ におい ては水と同程度または水よりも大きくなるためと考え られる.ここで, 付加的な極大值の大きさは上記の 3 つのケースでほぼ同じであるが, 付加的な極大位置は, $C=100 \mathrm{ppm}$ の $T=20^{\circ} \mathrm{C}$ およひ $T=25^{\circ} \mathrm{C}$ の場 合 $(y / \delta \simeq 0.7)$ は, $C=65 \mathrm{ppm}, T=20^{\circ} \mathrm{C}$ の場合 $(y / \delta \simeq 0.6)$ よりも境界層外縁に近くなる. また, 抵抗 低減率が最も大きい $D R=69 \%$ の場合 $(C=65 \mathrm{ppm}$, $\left.T=25^{\circ} \mathrm{C}\right)$ には, 主流方向乱れ強さ分布に付加的な極 大值が見られず, $0.5<\delta / y<0.8$ において $u_{r m s}^{++}$はほ ぼ一定値となる。

3.6 壁面垂直方向乱れ強さ分布 図7(a) および 7 (b) にそれぞれ, 溶液濃度 $C=65 \mathrm{ppm}$ および 100 $\mathrm{ppm}$ における壁面垂直方向乱れ強さ $v_{r m s}^{\prime+}$ の分布を示 す. 溶液濃度 $C=65 \mathrm{ppm}$ の場合, $T=20^{\circ} \mathrm{C}(D R=$ $62 \%)$ および $T=25^{\circ} \mathrm{C}(D R=69 \%)$ では, $v_{r m s}^{++}$の分 布には水の場合に見られる明確な極大值が現れず，境 界層内全体にわたってほぼ一定值 $\left(v_{r m s}^{++} \simeq 0.5\right)$ とな り, 水の場合と比べてかなり小さくなる. $T=30^{\circ} \mathrm{C}$ $(D R=33 \%)$ および $T=35^{\circ} \mathrm{C}(D R=11 \%)$ では, $v_{r m s}^{\prime+}$ は水の值よりも大きい. 一方, 溶液濃度 $C=100$

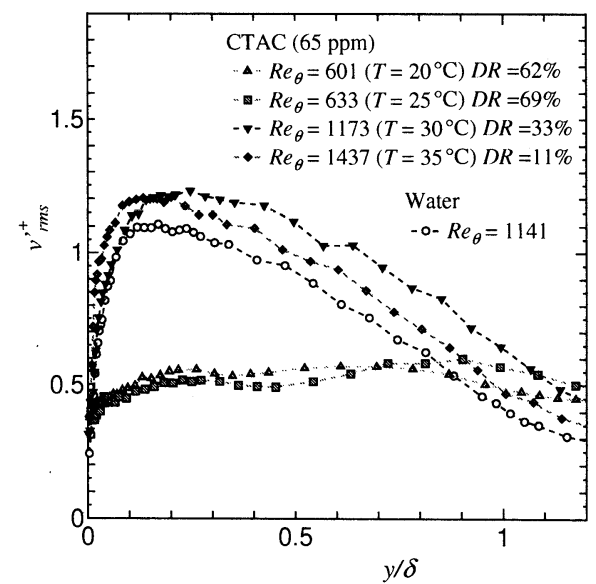

(a)

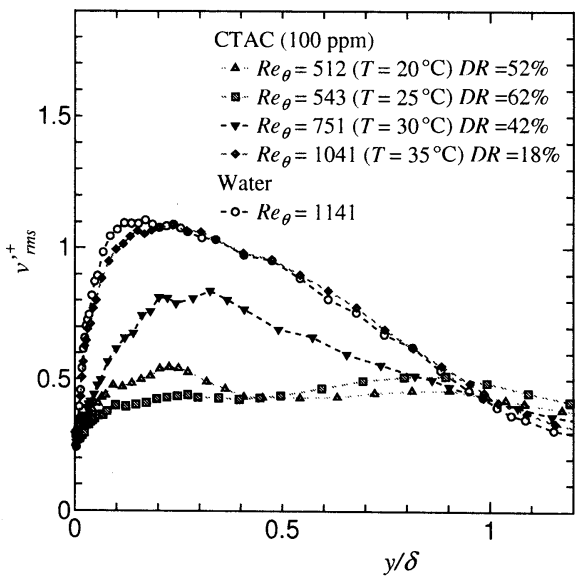

(b)

Fig. 7 Effect of solution temperature on wallnormal turbulence intensity: (a) $65 \mathrm{ppm}$, (b) $100 \mathrm{ppm}$.

$\operatorname{ppm}$ の場合, $T=25^{\circ} \mathrm{C}(D R=62 \%)$ では, $v_{r m s}^{++}$は 水のものよりもかなり小さくなり, 境界層内全体にわ たってほぼ一定值 $\left(v_{r m s}^{++} \simeq 0.5\right)$ となる. $T=20^{\circ} \mathrm{C}$ $(D R=52 \%)$ では, $y / \delta \simeq 0.2$ において最大值が見 られるものの, 水の值に比べるとかなり小さくなる. $T=30^{\circ} \mathrm{C}(D R=42 \%)$ では, $v_{r m s}^{++}$は, $T=20^{\circ} \mathrm{C}$ および $25^{\circ} \mathrm{C}$ の分布と水の分布とのほぼ中間に位置し, その最大位置は水のものよりも大きくなる. $T=35^{\circ} \mathrm{C}$ $(D R=18 \%)$ では, $v_{r m s}^{++}$の分布は水のものとほぼ一 致する.

以上の結果から, 壁面垂直方向乱れ強さ分布は, LDR 領域 $(0<D R<40 \%)$ では，水の值よりも僅か に大きいまたは水のものと同程度であること, HDR 領 域 $(40 \leq D R<60 \%)$ では，抵抗低減率が大きくなる ほど $v_{r m s}^{++}$が小さくなること, MDR 領域 $(D R \geq 60 \%)$ では，境界層内全体にわたってほぼ一定值となり，水 


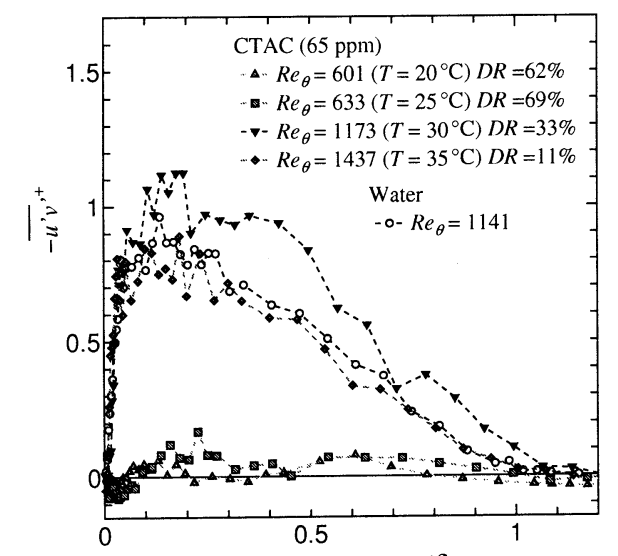

(a)

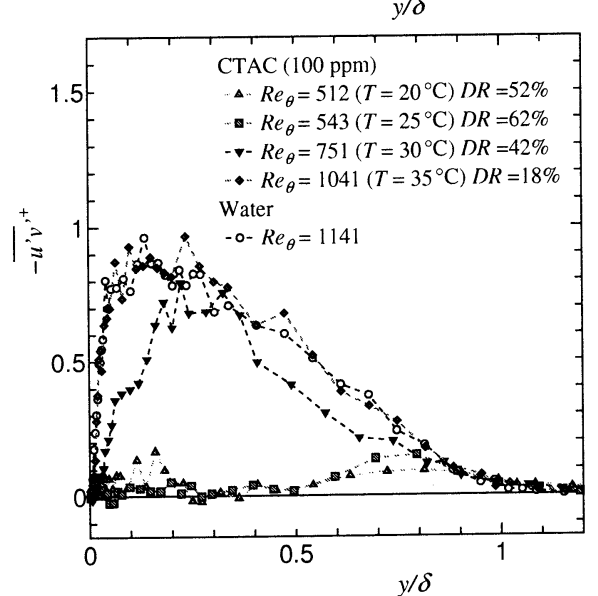

(b)

Fig. 8 Effect of solution temperature on Reynolds shear stress: (a) 65 ppm, (b) 100 ppm.

の場合と比べてかなり小さくなることが示された.つ まり, 壁面垂直方向乱れ強さ分布は, LDR 領域, HDR 領域，およびMDR 領域により整理されることが明ら かになった，なお，主流方向および壁面垂直方向乱れ 強さ分布の変化に伴う乱流構造の変化については, 今 後，PIV 計測により明らかにする予定である.

$3 \cdot 7$ レイノルズせん断応力分布 摩擦速度 $u_{\tau}$ に より正規化されたレイノルズせん断応力 $-\overline{u^{\prime} v^{\prime}}+$ の分 布を図 8 に示す. 溶液濃度 $C=65 \mathrm{ppm}$ の場合, $T=$ $20^{\circ} \mathrm{C}(D R=62 \%)$ および $T=25^{\circ} \mathrm{C}(D R=69 \%)$ で は, 境界層全体にわたって $-\overline{u^{\prime} v^{\prime}}$ の值は極めて小さ く，水の場合に見られる壁面近傍の明確な極大值は見 られないが，境界層中央部付近 $(y / \delta \simeq 0.6)$ に僅かな 極大值が現れる.この極大值は主流方向乱れ強さ分布 において見られた付加的な極大值と対応している (図 6 参照 $) . T=30^{\circ} \mathrm{C}(D R=33 \%)$ では, $-\overline{u^{\prime} v^{\prime}}+$ は水の 值よりも大きくなり, $T=35^{\circ} \mathrm{C}(D R=11 \%)$ では水 の分布とほぼ一致する. 一方, 溶液濃度 $C=100 \mathrm{ppm}$
Table 3 Comparison of mean velocity and streamwise turbulence intensity between two cases that the drag reduction ratio and the Reynolds number are similar.

\begin{tabular}{c|cc|ccc|cc}
\hline \hline Case & $D R(\%)$ & $R e_{\theta}$ & $C(\mathrm{ppm})$ & $T\left({ }^{\circ} \mathrm{C}\right)$ & $x(\mathrm{~mm})$ & $U^{+}$ & $u_{r m s}^{\prime+}$ \\
\hline \multirow{2}{*}{1} & 62 & 601 & 65 & 20 & 1000 & $\bigcirc$ & $\bigcirc$ \\
& 62 & 543 & 100 & 25 & 1000 & $\bigcirc$ & \\
\hline \multirow{2}{*}{2} & 21 & 357 & 65 & 20 & 300 & $\bigcirc$ & $\times$ \\
& 19 & 346 & 150 & 20 & 500 & & \\
\hline \multirow{2}{*}{3} & 55 & 535 & 65 & 20 & 800 & $\bigcirc$ & $\times$ \\
& 52 & 512 & 100 & 20 & 1000 & & \\
\hline \multirow{2}{*}{4} & 49 & 483 & 100 & 20 & 500 & $\bigcirc$ & $\times$ \\
& 46 & 444 & 65 & 20 & 300 & & \\
\hline \multirow{2}{*}{5} & 37 & 403 & 100 & 20 & 500 & $\bigcirc$ & $\times$ \\
& 34 & 463 & 150 & 20 & 1000 & & \\
\hline \multirow{2}{*}{6} & 12 & 339 & 100 & 20 & 300 & $\bigcirc$ & $\bigcirc$ \\
& 8 & 301 & 150 & 20 & 300 & & \\
\hline \hline
\end{tabular}

の場合, $T=20^{\circ} \mathrm{C}(D R=52 \%)$ および $T=25^{\circ} \mathrm{C}$ $(D R=62 \%)$ では, $-\overline{u^{\prime} v^{\prime}}+$ の值は境界層全体にわたっ て極めて小さいが，境界層中央部付近 $(y / \delta \simeq 0.7)$ に 極大值が現れる. 溶液濃度 $C=100 \mathrm{ppm} の-{\overline{u^{\prime} v^{\prime}}}^{+}$ の極大位置は, $C=65 \mathrm{ppm}$ のものよりも壁面から離 れており，この大小関係は主流方向乱れ強さ分布の付 加的な極大位置の大小関係と同じである (図 6 参照). $T=30^{\circ} \mathrm{C}(D R=42 \%)$ では, $-\overline{u^{\prime} v^{\prime}}+$ は, 水のもの よりも小さく, その最大位置 $y / \delta$ は水のものよりも大 きくなる. $T=35^{\circ} \mathrm{C}(D R=18 \%)$ では, $-{\overline{u^{\prime} v^{\prime}}}^{+}$は 水の分布とほぼ一致する.

以上の結果より，レイノルズせん断応力 $-{\overline{u^{\prime} v^{\prime}}}^{+}$の 值は，LDR 領域では水の值よりも僅かに大きいまたは 水のものと同程度であること，ならびに MDR 領域で は境界層内全体にわたってほぼゼロとなることが明ら かになった．また，HDR 領域では抵抗低減率が大きく なる程 $-{\overline{u^{\prime} v^{\prime}}}^{+}$は小さくなる.ただし, $C=100 \mathrm{ppm}$ の $T=20^{\circ} \mathrm{C}(D R=52 \%)$ と $T=30^{\circ} \mathrm{C}(D R=42 \%)$ とでは, $-{\overline{u^{\prime} v^{\prime}}}^{+}$の值がかなり異なることに注意され たい.

3.8 同程度の抵抗低減率およびレイノルズ数におけ る平均速度分布と主流方向乱れ強さ分布の比較抵 抗低減率 $D R$ とレイノルズ数 $R e_{\theta}$ が同程度の場合に ついて, 平均速度 $U^{+}$および主流方向乱れ強さ $u_{r m s}^{\prime+}$ の分布を比較する. 抵抗低減率 $D R$ とレイノルズ数 $R e_{\theta}$ が同程度の場合として, 表 3 に示す 6 つのケー スを取り上げる，表 3 には，本論文で示した異なる溶

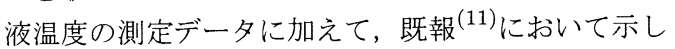
た異なる溶液濃度ならびに主流方向位置における測定 データも使用されている，また，表 3 には， $U^{+}$およ び $u_{r m s}^{++}$について, $D R$ と $R_{\theta}$ が同程度である $2 つ の$ 測定データが互いにほぼ一致する場合には○で, 一致 


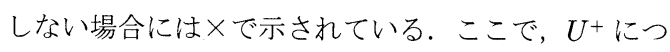
いてはその差が $5 \%$ 未満の場合を, $u_{r m s}^{++}$について その值と壁面近傍の最大位置が共に $10 \%$ 未満の場合 をそれぞれ一致するとした。

表 3 より, $D R$ と $\operatorname{Re}_{\theta}$ が同程度の場合, 平均速度 $U^{+}$の分布は全てのケースにおいて互いに良く一致す るが，主流方向乱れ強さ $u_{r m s}^{++}$の分布については互い に良く一致する場合と一致しない場合があり, $D R$ と $R e_{\theta}$ だけでは整理できないことが分かる. なお， $D R$ と $\operatorname{Re}_{\theta}$ が同程度の場合において, せん断粘度 $\eta$ の一 致の有無は, 主流方向乱れ強さ分布の一致の有無には 寄与しないことを確認している.

\section{4. 結言}

界面活性剂水溶液の溶液温度がゼロ圧力勾配平板上 乱流境界層の平均速度分布および乱れ統計量分布に 及ぼす影響を明らかにするために, 溶液濃度 $C=65$ $\mathrm{ppm}$ および $100 \mathrm{ppm}$ について, 溶液温度を $T=20^{\circ} \mathrm{C}$, $25^{\circ} \mathrm{C}, 30^{\circ} \mathrm{C}$, および $35^{\circ} \mathrm{C}$ と変化させて, 2 次元レー ザードップラー流速計 (LDV) による速度場計測を行 い, 以下の結論を得た。

(1) 抵抗低減率 $D R$ は溶液濃度 $T$ が $20^{\circ} \mathrm{C}$ から $25^{\circ} \mathrm{C}$ になると大きくなり, $T=25^{\circ} \mathrm{C}$ で最大抵抗低減率と なる. さらに, 溶液温度が $30^{\circ} \mathrm{C}, 35^{\circ} \mathrm{C}$ と高くなると 抵抗低減率は小さくなる。

(2) 外層スケールの平均速度分布は, LDR 領域 $(0<$ $D R<40 \%)$ では水の分布にほぼ一致し, HDR 領域 $(40 \leq D R<60 \%)$ では抵抗低減率の増加と共にブラジ ウスの層流速度分布に近づき, $M D R$ 領域 $(D R \geq 60 \%)$ では水の速度分布とブラジウスの層流速度分布のほぼ 中間に位置する.

(3) 壁変数で正規化された平均速度 $U^{+}$は抵抗低減 率 $D R$ の増加に伴い大きくなり, その分布形状は LDR 領域, HDR 領域, および MDR 領域により良く整理 される。

(4) 主流方向乱れ強さ分布および壁面近くの最大值 の大きさは抵抗低減率の大きさだけでは整理できない. また，抵抗低減率が比較的大きい場合 $(D R>50 \%)$ に，境界層中央部において付加的な極大值が現れる。

(5) 壁面垂直方向乱れ強さ $v_{r m s}^{\prime+}$ の值は, LDR 領域 では水の值よりも僅かに大きいまたは水のものと同程 度であり, HDR 領域では抵抗低減率が大きくなる程小 さくなり，MDR 領域では境界層内全体にわたってほ ぼ一定值となり, 水の場合と比べてかなり小さくなる.

(6) レイノルズせん断応力 $-\overline{u^{\prime} v^{\prime}}{ }^{+}$の值は, LDR 領 域では水の值よりも僅かに大きいまたは水のものと同
程度であり，HDR 領域では抵抗低減率が大きくなる 程 $-{\overline{u^{\prime} v^{\prime}}}^{+}$は小さくなり, MDR 領域では境界層内全 体にわたってほぼゼロとなる.

(7) 抵抗低減率 $D R$ とレイノルズ数 $R e_{\theta}$ が同程度の 場合, 平均速度 $U^{+}$の分布は互いに良く一致するが, 主流方向乱れ強さ $u_{r m s}^{\prime+}$ の分布については互いに良く 一致する場合と一致しない場合があり， $D R$ と $R e_{\theta} た ゙$ けでは整理できない.

\section{謝 辞}

本研究の一部は, 平成 19 年度科学研究費補助金基 盤研究 (C)（課題番号 No.19560170）の補助を受けて いる. また, 本研究に精力的に協力された名古屋工業 大学大学院生 竹内俊介氏に感謝する.

\section{文献}

(1) Itoh, M., Tamano, S., Yokota, K., and Ninagawa, M., Phys. Fluids, 17, No. 075107, (2005).

(2) White, C. M., Somandepalli, V. S. R., and Mungal, M. G., Exp. Fluids, 36, (2004), 62-69.

(3) Hou, Y., Somandepalli, V. S. R., and Mungal, M. G., Exp. Fluids, 40, (2006), 589-600.

(4) Chara, Z., Zakin, J.L., Severa, M. and Myska, J., Exp. Fluids, 16, (1993), 36-41.

(5) Nowak, M., Exp. Fluids, 34, (2003), 397-402.

(6) Itoh, M., Imao, S., and Sugiyama, K., JSME Int. J., Ser. B, 40, (1997), 550-557.

(7) Warholic, M.D., Schmidt, G.M. and Hanratty, T.J., J. Fluid Mech., 388, (1999), 1-20.

(8) Kawaguchi, Y., Segawa, T., Feng, Z. and Li, P., Int. J. Heat Fluid Flow, 23, (2002), 700-709.

(9) Yu, B., Li, F., and Kawaguchi, Y., Int. J. Heat Fluid Flow, 25, (2004), 961-974.

(10) Li, F.-C., Kawaguchi, Y., Segawa, T., and Hishida, K., Phys. Fluids, 17, No. 075104, (2005).

(11) Tamano, S., Itoh, M., Inoue, T., Yokota, K., Effects of concentration of surfactant solutions on dragreducing turbulent boundary layer, Trans. JSME, Ser. B, No. 07-0969, submitted.

(12) Dimitropoulos, C. D., Dubief, Y., Shaqfeh, E. S. G., Moin, P., and Lele, S. K., Phys. Fluids, 17, No. 011702, (2005).

(13) Dimitropoulos, C. D., Dubief, Y., Shaqfeh, E. S. G., and Moin, P., J. Fluid Mech., 566, (2006), 153-162.

(14) Tamano, S., Itoh, M., Hoshizaki, K., and Yokota, K., Phys. Fluids, 19, (2007), No. 075106.

(15) Li C.-F., Sureshkumar R., and Khomami B., J. Non-Newtonian Fluid Mech., 140, (2006), 23-40.

(16) Gyr, A. and Bewersdorff, H.-W., Drag Reduction of Turbulent Flows by Additives, Kluwer, Dordrecht, the Netherlands (1995).

(17) Coles, D.E., Rand Rep., R-403-PR, (1962).

(18) Schlichting, H., Boundary-Layer Theory 7th edn, McGraw-Hill, (1979).

(19) Virk, P.S., AIChE J., 21 (4), (1975), 625-656. 